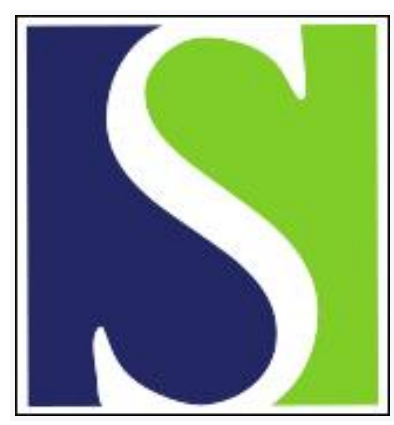

Scand J Work Environ Health 1994;20(3):213-215

https://doi.org/10.5271/sjweh.1406

Issue date: 01 Jun 1994

Pleural mesothelioma and asbestos exposure among Italian oil refinery workers.

by Gennaro V, Ceppi M, Boffetta P, Fontana V, Perrotta A

Affiliation: Environmental Epidemiology Department, Istituto Nazionale per la Ricerca sul Cancro (IST) (National Institute for Research on Cancer), Genoa, Italy.

The following articles refer to this text: 1995;21(4):301-309;

2014;40(4):361-369

This article in PubMed: www.ncbi.nlm.nih.gov/pubmed/7973494

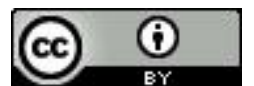




\title{
Pleural mesothelioma and asbestos exposure among Italian oil refinery workers
}

\author{
by Valerio Gennaro, MD, ${ }^{1}$ Marcello Ceppi, MS, ${ }^{1}$ Paolo Boffetta, MD, ${ }^{2}$ Vincenzo Fontana, MS, ${ }^{1}$ \\ Alessandra Perrotta, MS ${ }^{1}$
}

\begin{abstract}
GENNARO V, CEPPI M, BOFFETTA P, FONTANA V, PERROTTA A. Pleural mesothelioma and asbestos exposure among Italian oil refinery workers. Scand J Work Environ Health 1994;20:213-5.

OB.Jectives - The association between asbestos exposure and risk of mesothelioma was studied among workers from two oil refineries located in the northern Italian cities of Genoa and La Spezia, given that previous cohort analyses revealed two clusters of mesotheliomas and that international cohort studies have so far not reported an excess of this neoplasm among oil refinery workers.

Methods - Men $(\mathrm{N}=2300)$ who had been employed between 1914 and 1988 in two oil refineries located in northern Italy were studied. The follow-up covered the mortality of 639 white-collar and 1661 blue-collar workers from 1950 to 1991.

Results - Among the cases, the median duration of employment was 14.5 years, and the median time since first employment was 27.5 years. The job titles of the 10 men with pleural mesothelioma were maintenance worker (seven men), electrician (one man) and unspecified blue-collar worker (two men). Blue-collar workers experienced a significantly increased risk of pleural neoplasms, five deaths in each plant, in respect to both the provincial [standardized mortality ratio (SMR) 266] and national (SMR 1663) reference populations. The SMR, based on eight deaths, was 320 for workers with more than 10 years of employment and 20 years since first exposure.

Conclusions - The results uphold the notion that exposure to asbestos in oil refineries causes pleural mesotheliomas. This is the first study to find an excess of pleural mesotheliomas among oil refinery workers exposed to asbestos.
\end{abstract}

KEY woros - cohort study, employment, fibers, late effects, mortality, occupation, petroleum workers, pleural tumor.

In oil refinery plants, asbestos is used mainly as a thermal insulator or gasket material and for protective screens around on-site welding operations. Other carcinogens, or agents suspected as such, in oil refineries include arsenic compounds, hexavalent chromium, nickel, mixtures of polycyclic aromatic hydrocarbons (PAH), and silica. Although mesothelioma is known to be caused by asbestos exposure, international cohort studies have so far not reported an excess of this neoplasm among oil refinery workers (1). Employment in oil refineries was classified by the International Agency for Research on Cancer (IARC) as probably involving a carcinogenic risk to humans (IARC group 2A). This evaluation was based on the increased risk of leukemia among boilermakers and pipe fitters exposed to benzene and of skin cancer among wax pressmen. However, many years ago, Lilis et al (2) suggested that the number of pleural mesotheliomas and lung cancers might increase

Environmental Epidemiology Department, Istituto Nazionale per la Ricerca sul Cancro (IST) (National Institute for Research on Cancer), Genoa, Italy.

2 Unit of Analytical Epidemiology, International Agency for Research on Cancer, Lyon, France.

Reprint requests to: Dr V Gennaro, Istituto Nazionale per la Ricerca sul Cancro (IST), Environmental Epidemiology, Viale Benedetto XV 10, I-16132 Genoa, Italy. among maintenance workers in oil refineries as a consequence of the growth of oil refining and chemical industries.

We studied the association between asbestos exposure and the risk of mesothelioma among workers from two oil refineries, one located in Genoa and the other in La Spezia, in northern Italy, given that previous and preliminary cohort studies of these populations revealed two clusters of mesotheliomas (3). The two provinces in which the plants are located have the highest mortality rates for pleural mesotheliomas in Italy, mainly because of widespread asbestos exposure in shipbuilding [mortality rate for men in 1975-1977 (Italian standard) Genoa: 4.8/ 100 000; La Spezia: 6.1/100 000; Italy: 0.9/100 000).

\section{Subjects and methods}

Personal information, including name, gender, date of birth, address, registration number, job title, age at hiring, and period of employment, was obtained from company records. The subjects were classified as blue- or white-collar workers from the job titles provided by the companies. Maintenance workers represented $50 \%$ of the blue-collar workers in $\mathrm{La}$ Spezia. In both cohorts women were excluded from the analysis because of their low number (about $9 \%$ ).

In La Spezia, 932 men were employed between 1914 and 1977, and the follow-up covered the mor- 
Table 1. Number of workers, person-years, and deaths from pleural mesothelioma in the two oil refinery plants.

\begin{tabular}{|c|c|c|c|c|c|c|c|c|c|}
\hline \multirow[b]{2}{*}{ Group } & \multicolumn{3}{|c|}{ La Spezia refinery } & \multicolumn{3}{|c|}{ Genoa refinery } & \multicolumn{3}{|c|}{ Total } \\
\hline & $\begin{array}{l}\text { Workers } \\
\text { (N) }\end{array}$ & $\begin{array}{l}\text { Person- } \\
\text { years } \\
\text { (N) }\end{array}$ & $\begin{array}{l}\text { Deaths } \\
\text { (N) }\end{array}$ & $\begin{array}{l}\text { Workers } \\
(\mathrm{N})\end{array}$ & $\begin{array}{l}\text { Person- } \\
\text { years } \\
\text { (N) }\end{array}$ & $\begin{array}{l}\text { Deaths } \\
\text { (N) }\end{array}$ & $\begin{array}{l}\text { Workers } \\
\text { (N) }\end{array}$ & $\begin{array}{l}\text { Person- } \\
\text { years } \\
\text { (N) }\end{array}$ & $\begin{array}{l}\text { Deaths } \\
\text { (N) }\end{array}$ \\
\hline $\begin{array}{l}\text { White-collar workers } \\
\text { Blue-collar workers }\end{array}$ & $\begin{array}{l}221 \\
711\end{array}$ & $\begin{array}{r}6277 \\
18978\end{array}$ & $\overline{5}$ & $\begin{array}{l}418 \\
950\end{array}$ & $\begin{array}{l}10224 \\
22901\end{array}$ & $\overline{5}$ & $\begin{array}{r}639 \\
1661\end{array}$ & $\begin{array}{l}16501 \\
41879\end{array}$ & $\overline{10}$ \\
\hline Total & 932 & 25255 & 5 & 1368 & 33125 & 5 & 2300 & 58380 & 10 \\
\hline
\end{tabular}

Table 2. Mortality from pleural mesotheliomas in two oil refinery cohorts (blue-collar workers only). (SMR = standardized mortality ratio, $95 \% \mathrm{Cl}=95 \%$ confidence interval)

\begin{tabular}{|c|c|c|c|c|c|}
\hline \multirow{3}{*}{ Refinery } & \multirow{3}{*}{$\begin{array}{l}\text { Deaths } \\
\text { (N) }\end{array}$} & \multicolumn{4}{|c|}{ Type of reference population } \\
\hline & & \multicolumn{2}{|c|}{ Provincial } & \multicolumn{2}{|c|}{ National } \\
\hline & & SMR & $95 \% \mathrm{Cl}$ & SMR & $95 \% \mathrm{Cl}$ \\
\hline $\begin{array}{l}\text { Genoa } \\
\text { La Spezia }\end{array}$ & $\begin{array}{l}5 \\
5\end{array}$ & $\begin{array}{l}388 \\
203\end{array}$ & $\begin{array}{r}126-904 \\
66-473\end{array}$ & $\begin{array}{l}1926 \\
1435\end{array}$ & $\begin{array}{l}624-4487 \\
465-3344\end{array}$ \\
\hline Total & 10 & 266 & $128-489$ & 1663 & $797-3058$ \\
\hline
\end{tabular}

tality of 221 white-collar and 711 blue-collar workers from 1955 to 1991 . In Genoa, 1368 men were employed between 1949 and 1988, and the followup from 1950 to 1991 covered the mortality of 418 white-collar and 950 blue-collar workers.

For the refinery workers vital status was ascertained by postal follow-up up to 1987 (1991 for the La Spezia cohort). In addition, an automatic record linkage was performed for the Genoa cohort with the mortality records for the years 1988-1991.

Causes of deaths were found in the regional and national mortality files and coded according to the eighth revision of the International Classification of Diseases (ICD-8). Six percent of the La Spezia workers and $7 \%$ of the Genoa workers were lost to follow-up.

The expected number of pleural neoplasms was obtained by multiplying the age-specific mortality rates of the national or provincial reference populations by the person-years of the corresponding age groups. Three age groups $(25-54,55-74, \geq 75$ years) were used. The reference rates of 1975-1977 were applied to the whole study period (4).

The number of observed deaths among the bluecollar workers (including maintenance workers) was compared with the number expected to obtain the standardized mortality ratios (SMR). The standardized mortality ratios, based on the Poisson distribution, and $95 \%$ confidence intervals $(95 \% \mathrm{CI})$ were calculated with two-tailed significance tests using the statistical package Epilog (5).

\section{Results}

Among the blue-collar workers, a significant excess risk for pleural neoplasms was detected in both plants, five deaths in each. The numbers of workers and person-years are shown in table 1 .

Overall, five cases had pleural mesothelioma specified on the death certificates, while the diagnosis was less precise in the remaining cases.

The refinery workers in both cohorts showed an increased risk of pleural neoplasms in respect to both the provincial and national reference populations (table 2). However, the standardized mortality ratio was not significantly increased when the La Spezia cohort was compared with the local population. In each plant the standardized mortality ratios were higher for persons aged 75 years and over, and there was a positive trend with age.

A standardized mortality ratio of $266(95 \% \mathrm{CI}$ 128 - 489) was calculated from the combined data of the two cohorts (table 3 ).

For the cases, the median duration of employment was 14.5 (range $1-33$ ) years, and the median time since first employment was 27.5 (range $11-53$ ) years.

The job titles of the 10 men with pleural mesothelioma were maintenance worker (two men in Genoa and five men in La Spezia), electrician (one man in Genoa), and unspecified blue-collar worker (two men in Genoa).

For the workers with more than 10 years of employment and 20 years since first exposure, a threefold increased risk for pleural mesotheliomas ( 8 deaths, SMR $320,95 \%$ CI 138 -631) was observed (table 3 ). However, no consistent pattern was noted when the two plants were analyzed separately (data not shown in detail).

\section{Discussion}

Mortality from pleural mesotheliomas has risen during the last few decades in Italy (SMR 106 in 19691973 versus SMR 165 in $1984-1988)(6)$. It is therefore likely that, in our study, the use of $1975-1977$ rates for the whole period of follow-up caused a slight underestimate of the standardized mortality ratios for the period before 1975 and an overestimate for the period after 1977 .

Although the group of workers actually exposed to asbestos in the oil refineries was probably small, in both plants, all of the pleural tumors were detected only among employees, in particular maintenance 
Table 3. Mortality rates for pleural mesothelioma in the two oil refineries combined (blue-collar male workers) by duration of exposure and time since first exposure. [SMR = standardized mortality ratio (versus provincial reference populations), $95 \%$ $\mathrm{Cl}=95 \%$ confidence interval $]$

\begin{tabular}{|c|c|c|c|c|c|c|c|c|c|}
\hline \multirow{3}{*}{$\begin{array}{l}\text { Duration } \\
\text { of exposure }\end{array}$} & \multicolumn{9}{|c|}{ Time since first exposure } \\
\hline & \multicolumn{3}{|c|}{$\leq 20$ years } & \multicolumn{3}{|c|}{$>20$ years } & \multicolumn{3}{|c|}{ Total } \\
\hline & Deaths & SMR & $95 \% \mathrm{Cl}$ & Deaths & SMR & $95 \% \mathrm{Cl}$ & Deaths & SMR & $95 \% \mathrm{Cl}$ \\
\hline $\begin{array}{l}\leq 10 \text { years } \\
>10 \text { years }\end{array}$ & $\begin{array}{l}1 \\
1\end{array}$ & $\begin{array}{l}214 \\
228\end{array}$ & $\begin{array}{l}5-1192 \\
6-1269\end{array}$ & $-\overline{8}$ & $\begin{array}{r}0 \\
320\end{array}$ & $138-631$ & $\begin{array}{l}1 \\
9\end{array}$ & $\begin{array}{l}122 \\
306\end{array}$ & $\begin{array}{r}3-682 \\
140-581\end{array}$ \\
\hline Total & 2 & 221 & $27-797$ & 8 & 281 & $121-553$ & 10 & 266 & $128-489$ \\
\hline
\end{tabular}

workers, probably exposed to asbestos. Indeed, a hygienic survey conducted using infrared spectrophotometry detected crocidolite around pipes and amosite fibers in topping and preheating areas in the Genoa oil refinery. In the La Spezia refinery, in many sites of the boiler areas, each sample measured by the diffractometric method and polarized light microscope revealed a concentration of $95 \%$ amosite, crocidolite, and chrysotile. Amosite fibers were also found around pipes.

All of the cases were documented on the death certificates by a general practitioner, and $50 \%$ were confirmed as pleural mesotheliomas. However, the cases were not histologically confirmed, and no asbestos bodies were searched for. Although an underestimate of pleural tumor deaths due to the misclassification of some pleural mesotheliomas as lung cancers was possible, because autopsy is seldom performed in Genoa and La Spezia (as in Italy in general), it is likely that the number of pleural mesotheliomas, but not the standardized mortality ratios, has been underestimated for these cohorts.

The higher rate of pleural mesothelioma in Genoa and La Spezia compared with the whole of Italy is probably due to the widespread use of asbestos in many industries, especially shipbuilding. Therefore occupational exposure to asbestos outside employment in oil refineries is likely to have been a confounder in these cohorts. However, the use of provincial mortality rates might to some extent control its effect. On the other hand, the analyses of duration of employment and time since first employment with the two cohorts combined revealed a trend according to both variables. This finding suggests a role of exposure to asbestos inside the refinery.

This issue cannot be completely solved on the basis of these data, and it will be studied in detail in a case-referent study in which the entire occupational history of the workers will be evaluated. In our opinion, pleural mesotheliomas should be considered an occupational disease among oil refinery workers since the use of asbestos has been widespread in this work and many of the workers share the same environment.

\section{Acknowledgments}

We are grateful to Dr T Partanen, Dr R Puntoni, and Mr T Wiley for their helpful comments. We thank Drs M Doria, E Garrone, C Lando, S Silvano, A Manti, and the Regional Mortality Registry (Regione Liguria) for the data collection. We also thank the IIP Plant (La Spezia) and the ERG Plant (Genoa) for their collaboration in providing employee data.

\section{References}

1. International Agency for Research on Cancer (IARC). Occupational exposures in petroleum refining: crude oil and major petroleum fuels. Lyon: IARC, 1989. IARC monographs on the evaluation of carcinogenic risks to humans; vol 45.

2. Lilis R, Daum S, Anderson H, Andrews G Selikoff IJ. Asbestosis among maintenance workers. In: International Agency for Research on Cancer (IARC). Biological effects on mineral fibres. Lyon: IARC, 1980:795810. IARC scientific publication; no 30 .

3. Gennaro V, Ceppi M, Fontana V, Beggi A, Puntoni R, Montemanni M, et al. Is the oil refinery a dangerous workplace for pleural tumor? Eur J Cancer 1991;27 suppl 3:S47.

4. Cislaghi C, Decarli A, La Vecchia C, Laverda N, Mezzanotte G, Smans M. Data, statistics and maps on cancer mortality: Italy 1975-1979. Bologna: Pitagora Editor, 1986:386--90.

5. Epicenter Software. Epilog plus: statistics package for epidemiology and clinical trials. Pasadena, CA: Epicenter software, 1984.

6. Facchini U, Branzaglia P, Ludwig N, Riboldi L, Bertazzi PA. Rischio amianto: uno studio sui certificati di morte per mesotelioma della pleura, 1969-1988. Acta Oncol 1993;14:221-31.

Received for publication: 2 December 1993 